\title{
Development of Multimedia Learning of Cell Material in Senior HIGH SCHOOL
}

\author{
Indah Purnamasari $^{1)}$, Fadillah $^{2)}$, Warneri ${ }^{3)}$ \\ ${ }^{1)}$ Universitas Tanjungpura, Pontianak, Indonesia \\ E-mail: indahpurnamasari93.ds@gmail.com \\ ${ }^{2)}$ Universitas Tanjungpura, Pontianak, Indonesia \\ E-mail: fadillahkn@gmail.com \\ ${ }^{3)}$ Universitas Tanjungpura, Pontianak, Indonesia \\ E-mail:warneri@yahoo.com
}

\begin{abstract}
This study aims to describe the design of multimedia learning, to determine the feasibility and to determine the affective and psychomotor of students. The method in this research is the method of research and development or research and development using the 4D model, namely the definition, design and development. Participants of this study were biology subject teachers and students of class XI at SMA Negeri 2 Teluk Keramat. Data collection technique used observation, interview and documentation. Data were analyzed qualitatively and quantitatively. From the results of the validation of media experts, material experts and design experts obtained an average value of 4.33 with very valid criteria which means that multimedia learning is very feasible to use for field trials. Assessment of affective and psychomotor of students obtained an average of 3.5 and 3.6 with excellent criteria. From the results of product validation and testing that multimedia learning can help teachers in the learning process to create interesting learning for students.
\end{abstract}

Keywords: Development; Multimedia Learning; Cell-Material

\section{INTRODUCTION}

The importance of the role of education in human life needs to be well developed and implemented. Components required to support the development of knowledge in the future. This future education is greatly influenced by technological developments that are very rapidly developing and encouraging renewal efforts in utilizing the results of technology in the learning process at school using learning media. Learning media are tools that can facilitate or help students achieve learning goals and are useful for conveying messages or information. This is in line with the opinion of Suryani and Agung (2012) in Suryani et al. (2018: 2), the media are everything that can be used to channel messages and can stimulate the mind, arouse enthusiasm, attention and willingness of students so as to encourage the occurrence of the process learning in students. According to Pribadi (2018: 157), learning media can be interpreted as something that carries information and knowledge that can be learned by students.
The use of instructional media can facilitate students to achieve the desired goals or competencies. By using the learning media all five students' senses can be used in their entirety, both through hearing, sight, and also touching. The availability of media in learning is expected to reduce the impression in the minds of students that the teacher as the only source of information for students. The use of instructional media as a tool during the process of learning activities can help realise the success of the teaching and learning process (Cahyaningtyas, 2017: 210). This is in line with the opinion of Miarso (2008) in Rusman (2013: 93), learning is the process of interaction of students with educators and learning resources in a learning environment. Learning will succeed if students have motivation in learning. In addition, according to Hamalik (2005), learning media is an element of learning, wherewith the help of the students can learn things that are needed in an effort to achieve learning goals.

One of the subjects that support the achievement of educational goals is Biology learning. Learning biology is learning about humans and their environment or learning 
about the problems of how humans develop a better life. Biology is part of the Natural Sciences (IPA) which examines living things and their environment which consists of processes, interactions between living things. This living creature has basic characteristics consisting of cells, development and growth, breathing, multiplying, responding to stimuli, metabolizing and adapting to the environment.

Based on observations at SMA Negeri 2 Teluk Keramat on Biology, especially on cell material, it shows that students' attitudes in learning pay attention to those who do not pay attention to the teacher explaining ahead by using picture media on the blackboard. Based on the results of interviews with a number of students, information was obtained that they thought learning was less interesting and boring because the teacher only explained on the blackboard while drawing cells, and they did not understand the material. In this case it is very necessary learning media in the learning process in order to attract student attention and motivate student learning. The learning media used are multimedia learning.

Multimedia learning is a combination of various media (audio, video, text, images, graphics, animation) that can be used to convey messages or information in the learning process that has been packaged into a digital file (computerized) using the Lectora Inspire software by reason of the Lectora Inspire software this is easily downloaded for free and its use is practical and easy. According to Smaldino et al. (2008) in Syriac et al. (2018: 195), multimedia is media that uses two or more elements of media consisting of text, graphics, images, photos, audio, video and animation in an integrated manner. Various multimedia features such as video/audio, quizzes, games, and animations that can help teachers in learning topics become more varied where multimedia contents have a strong impact on students' thoughts and feelings in learning (Alfar, 2009 in Diputra, 2016: 831).

Multimedia in learning is a combination of various media consisting of text, graphics, still images, animation, sound and video (Purwanto, 2005 in Syriac et al., 2018: 196). According to Krisnawati (2014: 2), multimedia learning is one of the learning components that have an essential role in the learning process. In general, the benefits of multimedia according to Daryanto (2016: 52) were that the learning process becomes more interesting, more interactive, the amount of teaching time can be reduced, the quality of student learning can be improved, and the teaching and learning process can be done anywhere and anytime, as well as student learning attitudes can be improved. In line with Munir's opinion (2015: 150) revealed that multimedia learning provides real and direct experience because students can communicate and interact with the environment in which they learn.

The formulation of the problem in this research is

1. How to design multimedia development of cell material learning in high school?

2. Are multimedia learning material cells worth using?
3. How are the results of the assessment of students' attitudes and skills on the cell material after using multimedia learning?

\section{Methodology}

The research method used in this research is research and development (Research and Development). According to Sugiyono (2014: 297), research and development methods are research methods used to produce certain products, and test the effectiveness of these products. This research aims to develop a learning product that can motivate and assist students in the learning process. In this study using the stages of the development of the 4D model designed by Thiagarajan (Mulyatiningsih, 2012: 195).

\section{A. Research Design}

The development model used is the 4D model (define, design, develop, and disseminate). The stages are as follows:

\section{1) Define Phase}

The definition includes initial analysis to gather information (curriculum, and learning media), analysis of student characteristics to determine student attitudes in learning, analysis of material here selects cell material, then formulates learning objectives based on material analysis.

\section{2) Design Phase}

The design phase includes the initial design that is making storyboards, selecting media using the Lectora Inspire software, selecting a format that is using exe format for media storage and packaged in a flash.

\section{3) The Development Stage}

The development phase includes validation of experts and user trials. Validation of experts was carried out by 3 lecturers, material experts, media experts and design experts. Next, a user trial is conducted, namely a field trial.

\section{4) Disseminate Stage}

Dissemination is carried out in the school where the research is but in another class.

\section{B. Participants and Data Collection}

The source of the data in this study is the subject of where the data was obtained. In this study using two data sources, namely: Primary Data, Data directly collected by researchers from the main source. As for the primary data sources in this study were biology subject teachers and students of class XI at SMA Negeri 2 Teluk Keramat. Secondary Data, Data directly collected by researchers as a primary source of data support. Secondary data in this study are documentation and questionnaires.

This research was conducted at SMA Negeri 2 Teluk Keramat on Biology subject for cell material in the 2018/2019 academic year. Data and information collection techniques by type are divided into two, namely direct observation and indirect observation. To obtain data in this 
study, researchers conducted with technique of direct observation, direct communication, and documentary study.

\section{Research Instruments}

In this study, researchers as the main instrument and use observation guidelines, interview guidelines, and documentation as a tool to obtain data in the field. There are three ways of data collection in this study namely observation, interview and documentation.

Observation, the observation technique used in this study was participant observation, with a data collection tool that is an observation sheet in which the researcher collected data by making observations directly. In this study, what was observed in this observation was a learning process to see students' attitudes and skills.

Interview, interview techniques conducted by researchers in this study were conducted to teachers in the field of biology studies and class XI students of SMA Negeri 1 Teluk Keramat. The researcher interview sheet was used to obtain data about the learning process of cell material biology before using multimedia learning.

Documentation, documentary study is a data collection technique by collecting and analyzing documents, both written documents, images and electronics (Sukmadinata, 2017: 221). The researcher uses the camera to take photos of events during the study both when data retrieval through interviews and the learning process takes place.

\section{Data Analysis}

Data analysis techniques in this study were divided into qualitative and quantitative data analysis techniques. The explanation is as follows: Qualitative data analysis in this study will be used to answer research problems and describe the findings of research results from the multimedia development procedure of learning cell material in the form of input, criticism and improvement suggestions obtained from observation sheets and interview sheets. Quantitative data analysis techniques are used by researchers to analyze the results of data in the form of numbers obtained from the validation of experts, attitudes and skills of students in using multimedia learning. Data analysis of students' attitudes and skills assessment is done after the observer has filled in the observation sheet when the learning activities take place. The activities carried out to calculate the student attitude observation datasheet are: (1) recapitulating the observer's assessment results, (2) making and analyzing the results of the observation table, (3) calculating the number of assessment results in each aspect of the criteria 4,3,2, and 1 for each student and (4) calculate the total score of each aspect for all students with the formula in equation (1) (Sari, 2015).

$$
\text { Final score }=\frac{\text { Number of score }}{\text { Maximum score }} \times 4
$$

Note:

Maximum score $=$ number of indicators $\mathrm{x} 4$

(5) Calculate the average attitude assessment overall, and (6) match the average assessment results with the category of student attitude scores in Table I (Permendikbud No 81A: 2013: 49-50).

TABLE I

STUDENT VALUE CATEGORIES

\begin{tabular}{cc}
\hline Score & Categories \\
\hline $3,33<$ score $\leq 4,00$ & Very good \\
$2,33<$ score $\leq 3,35$ & Good \\
$1,33<$ score $\leq 2,32$ & Enough \\
score $\leq 1,32$ & Less \\
\hline
\end{tabular}

\section{RESULTS AND DISCUSSION}

A. Results

\section{1) Design Multimedia Learning Development}

The multimedia design development learning findings in this study are:

1) At the define stage, the following steps are carried out: Front and Analysis (Initial Analysis). In this preliminary analysis, observations and interviews with biology subject teachers were carried out. The findings in the field show that in SMA Negeri 2 Teluk Keramat use the media for learning pictures on the board and the environment around the school. Leaner Analysis (Analysis of Student Characteristics). The findings in the field show that the tendency to learn independently and the lack of interest in the learning process. Concept Analysis, in the analysis of this concept the findings in the field show that the cell material studied in class XI consists of several important concepts, namely: the concept of cells, prokaryotic and eukaryotic cells and cell transposition. Specifying Instructional Objectives (Formulating Learning Objectives). The learning objectives are (1) to explain the chemical components of cells, (2) to explain prokaryotic cells and eukaryotic cells, and (3) to explain cell transportation.

2) Design stage, the initial design (initial design), multimedia learning that is designed is packaged in a storyboard. Media selection (media selection) software chosen in the development of learning multimedia is Lectora Inspire. Format Selection, presenting the format used in the preparation of learning multimedia consists of exe format for media storage and packaged in a flash.

3) Develop phase, after the preparation of learning multimedia is completed and before it is tested on students the next stage of learning multimedia is validated by experts. The purpose of this validation is to determine the feasibility of the initial design of multimedia learning in aspects of media, learning design and material (content). The initial design of multimedia learning material for the structure and function of cells in this study will be validated by 1 expert lecturer of media expert, 1 lecturer of material expert and 1 lecturer of learning design expert. Learning multimedia validation experts refer to similar findings made with assessment criteria starting with the lowest assessment scores 1, 2, 3, 4 and 5 in each aspect. 
4) Disseminate, dissemination is carried out at SMA Negeri 2 Teluk Keramat to other teachers and classes.

\section{2) Feasibility Learning Multimedia}

Based on the results of the assessment conducted by learning design experts on the development of learning multimedia can be seen in Table II.

TABLE II

DESIGN EXPERT VALIDATION RESULTS

\begin{tabular}{|c|c|c|}
\hline No & Indicator & $\boldsymbol{A}_{\boldsymbol{i}}$ \\
\hline \multicolumn{3}{|c|}{ A. Title } \\
\hline 1 & $\begin{array}{l}\text { A brief description that includes the } \\
\text { application theme } \\
\text { A brief description that includes the } \\
\text { contents of the application }\end{array}$ & 5 \\
\hline \multicolumn{3}{|c|}{$\begin{array}{l}\text { B. Evaluation of Aspects of Learning } \\
\text { Objectives, Relation to SK / KD / } \\
\text { Curriculum / Material }\end{array}$} \\
\hline 1 & $\begin{array}{l}\text { Clarity of learning objectives } \\
\text { Connected learning objectives with } \\
\text { the KI / KD / Curriculum } \\
\text { The suitability of the material with } \\
\text { the learning objectives }\end{array}$ & 4 \\
\hline \multicolumn{3}{|c|}{$\begin{array}{l}\text { C. Assessment of Learning Contextual } \\
\text { and Actual Aspects }\end{array}$} \\
\hline 1 & Learning context & 4 \\
\hline 2 & Actual learning & 5 \\
\hline D. A & $\begin{array}{l}\text { essment of Problem Aspects } \\
\text { The suitability of the questions with } \\
\text { the learning objectives } \\
\text { Quality questions }\end{array}$ & $\begin{array}{l}4 \\
4\end{array}$ \\
\hline $\begin{array}{c}\text { E. } \mathbf{A} \\
1 \\
2 \\
\end{array}$ & $\begin{array}{l}\text { essment of Summary Aspects } \\
\text { Quality Summary } \\
\text { Appropriate references used }\end{array}$ & $\begin{array}{l}5 \\
5\end{array}$ \\
\hline \multicolumn{3}{|c|}{$\begin{array}{l}\text { F. Assessment of Physical Aspects of } \\
\text { Application }\end{array}$} \\
\hline 1 & $\begin{array}{l}\text { Winning presentation of images and } \\
\text { simulations }\end{array}$ & 5 \\
\hline 2 & $\begin{array}{l}\text { The utilisation of images and } \\
\text { simulations used }\end{array}$ & 5 \\
\hline 3 & $\begin{array}{l}\text { Accuracy in using text format and } \\
\text { format layout }\end{array}$ & 5 \\
\hline 4 & $\begin{array}{l}\text { Winning features and learning } \\
\text { media application icons }\end{array}$ & 4 \\
\hline 5 & $\begin{array}{l}\text { Attractive background design } \\
\text { learning media applications }\end{array}$ & 4 \\
\hline \multirow{3}{*}{\multicolumn{2}{|c|}{$\begin{array}{l}\text { Maximum Score } \\
\text { Score Obtained } \\
\text { Average }\end{array}$}} & 80 \\
\hline & & 71 \\
\hline & & 4.44 \\
\hline
\end{tabular}

$A_{i}=$ Average validation value for each aspect

$V_{a}=$ Average of total validations

Based on Table II, the design expert shows that the development of instructional multimedia has an average value of 4.44 with validity criteria that is very valid. Next, improvements were made based on suggestions and input from learning design experts.
TABLE III

RESULTS OF MEDIA EXPERT VALIDATION

\begin{tabular}{|c|c|c|}
\hline No & Indicator & $A_{i}$ \\
\hline \multicolumn{3}{|c|}{ A. Feasibility Assessment of Linguistic Aspects } \\
\hline 1 & Clarity of use instructions & 4 \\
\hline 2 & $\begin{array}{l}\text { Suitability of language with the } \\
\text { level of thinking of students } \\
\text { Suitability of language with the }\end{array}$ & 4 \\
\hline 3 & $\begin{array}{l}\text { level of emotional social } \\
\text { development of students }\end{array}$ & 4 \\
\hline 4 & $\begin{array}{l}\text { The ability to encourage students' } \\
\text { curiosity }\end{array}$ & 5 \\
\hline 5 & The modest use of language & 5 \\
\hline \multicolumn{3}{|c|}{ B. Feasibility Assessment Presentation Aspects } \\
\hline 1 & $\begin{array}{l}\text { Compilation of material } \\
\text { presentation }\end{array}$ & 4 \\
\hline 2 & $\begin{array}{l}\text { Support how the presentation of } \\
\text { learning media for the } \\
\text { involvement of students }\end{array}$ & 4 \\
\hline 3 & Presentation of pictures & 3 \\
\hline \multicolumn{3}{|c|}{$\begin{array}{l}\text { C. Assessment of Aspects of Media Effects on } \\
\text { Learning }\end{array}$} \\
\hline 1 & Ease of use & 5 \\
\hline 2 & $\begin{array}{l}\text { The ability of the media to } \\
\text { increase motivation }\end{array}$ & 4 \\
\hline 3 & $\begin{array}{l}\text { The ability of the media to } \\
\text { increase knowledge }\end{array}$ & 4 \\
\hline \multicolumn{3}{|c|}{ D. Feasibility Assessment Appearance } \\
\hline 1 & Winning the media preview & 4 \\
\hline 2 & The regularity of media design & 4 \\
\hline 3 & $\begin{array}{l}\text { The choice of type and font size } \\
\text { supports the media to be more } \\
\text { attractive }\end{array}$ & 4 \\
\hline 4 & $\begin{array}{l}\text { Compatibility of pictures and } \\
\text { videos with the material }\end{array}$ & 3 \\
\hline 5 & Ease of reading texts/writings & 4 \\
\hline 6 & Color selection & 4 \\
\hline \multirow{3}{*}{\multicolumn{2}{|c|}{$\begin{array}{l}\text { Maximum Score } \\
\text { Score Obtained } \\
\text { Average } \\
\end{array}$}} & 85 \\
\hline & & 69 \\
\hline & & 4.06 \\
\hline
\end{tabular}

$A_{i}=$ Average validation value for each aspect

$V_{a}=$ Average of total validations

Based on Table III, the validation of media experts shows that the development of instructional multimedia shows the results of an average value of 4.06 with validity criteria that is valid. After that a revision is made, and the input and advice given by the learning design expert.

Based on Table IV, the development of learning multimedia results an average value of 4.50 , the learning multimedia is categorised as very valid and deserves to be tested on students. During the field trial phase, the researchers conducted at SMA Negeri 2 Teluk Keramat with a total of 35 students. Learning multimedia is said to be feasible to use after being validated by experts in the material, media and design with an average validity of 4.33 with very valid criteria. 
TABLE IV

RESULTS OF MATERIAL EXPERT VALIDATION

\begin{tabular}{|c|c|c|}
\hline No & Indicator & $\boldsymbol{A}_{\boldsymbol{i}}$ \\
\hline 1 & $\begin{array}{l}\text { Conformity of material content } \\
\text { with basic competencies (KD) } \\
\text { and learning objectives }\end{array}$ & 5 \\
\hline 2 & Development of indicators & 4 \\
\hline 3 & $\begin{array}{l}\text { The truth of the concept of matter } \\
\text { in terms of scientific aspects }\end{array}$ & 4 \\
\hline 4 & Clarity of learning topics & 4 \\
\hline 5 & Material congestion & 5 \\
\hline 6 & Scope of material & 5 \\
\hline 7 & Material completeness & 4 \\
\hline 8 & $\begin{array}{l}\text { Suitability of the level of } \\
\text { difficulty with students' cognitive } \\
\text { development }\end{array}$ & 4 \\
\hline 9 & Clarity of example & 4 \\
\hline 10 & $\begin{array}{l}\text { Accuracy of material and } \\
\text { examples for developing learning } \\
\text { independence }\end{array}$ & 5 \\
\hline 11 & $\begin{array}{l}\text { Key truths of the answers } \\
\text { presented }\end{array}$ & 5 \\
\hline 12 & $\begin{array}{l}\text { Loads of cognitive aspects, on the } \\
\text { material, presented }\end{array}$ & 5 \\
\hline \multicolumn{2}{|c|}{ Maximum Score } & 60 \\
\hline \multicolumn{2}{|c|}{ Score obtained } & 54 \\
\hline \multicolumn{2}{|c|}{ Average } & 4.50 \\
\hline
\end{tabular}

$A_{i}=$ Average validation value for each aspect

$V_{a}=$ Average of total validations

\section{3) Obtaining Assessment of Student Attitudes and Skills}

\section{a. Attitude Assessment}

Attitude assessment is carried out during the research process. Some findings related to student learning outcomes in this study are Attitude assessment is carried out 2 times during teaching and learning activities in a computer room and carried out by two observers. From the assessment of student attitudes, each meeting obtained the results that student attitudes showed very good categories. The average value of each aspect is 4 . The results of student attitudes can be seen in Fig. 1.

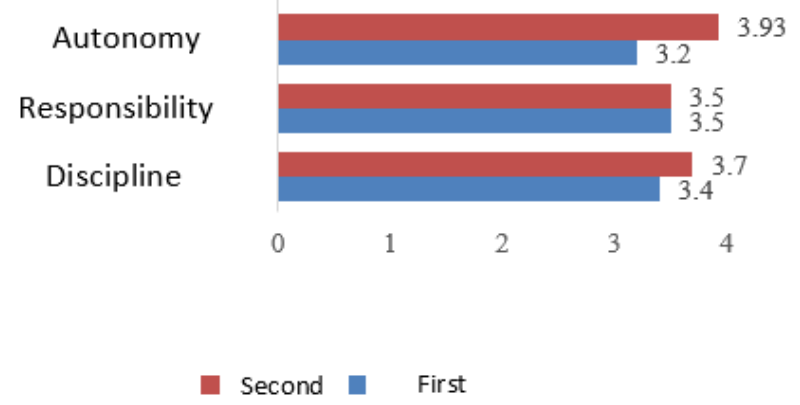

Fig. 1 Results of student attitude assessment

Based on Fig. 1, it was concluded that during the process each aspect, namely discipline, responsibility, independence, increased. So that learning activities using multimedia learning can improve discipline, responsibility and independence of students with a very good average rating.

\section{b. Psychomotor Assessment}

Assessment of student or psychomotor skills is done when students are brave or enthusiastic in asking questions and answering questions. The findings obtained are:

a. The skills assessment was carried out by two observers. Skills assessment includes students who are enthusiastic or brave in asking questions and answering questions from both the teacher and other students.

b. The results of the assessment showed students were enthusiastic in asking and answering questions from the teacher and other students with an average grade of 3.6 which was included in the excellent category.

c. Data on the results of the assessment of student skills can be seen in Fig. 2 .

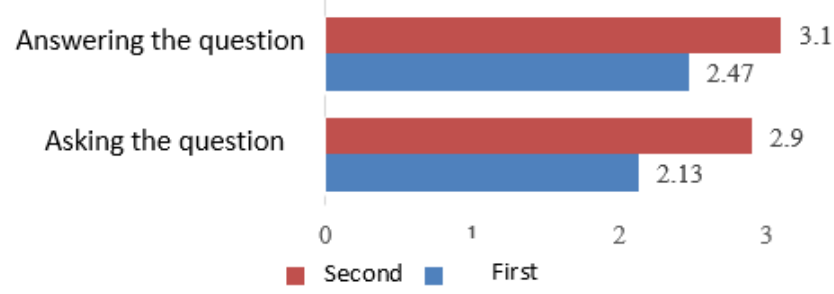

Fig. 2 Results of student skills assessment

Based on Fig. 2, it was concluded during the learning activities from meeting one to the second meeting, overall there was an increase in each aspect of skills in asking questions and answering questions.

\section{B. Discussion}

\section{1) Design Multimedia Learning Development}

The design of multimedia learning development in this study uses the 4D development model. The findings in the field at the stage of defining the media used so far in the learning process are still using image media. So that researchers create a media in the form of multimedia learning using Lectora Inspire software, this is done so that students are more motivated to learn and make learning more interesting. In line with the opinion of Sujoko (2013: 71) in Yanti and Eka (2017: 18), the learning process becomes more interesting when using the right media so that students are motivated to love the knowledge they are learning.

Furthermore, at the design stage, it is done by designing a learning media that is prepared using storyboards in advance to facilitate the process of making these media. After that it is packaged in a flash using exe format. The use of this exe format was chosen because it is easy to operate on any program. In line with the opinion of Sofyan et al. (2011: 6), learning multimedia developed has a loader type format $*$ exe and * swf where both types of formats can be opened on a computer that has a flash player installed. 
Next, the development stage is carried out by expert validation and user trials. After the media is finished, validation is carried out by material experts, media experts and design experts. Then the revisions were made according to the suggestions and input from the experts until the multimedia learning was developed until it was declared valid or feasible to be used or tested. Next, a field trial was conducted with 35 students to see students' responses to multimedia learning. The last stage is the dissemination stage carried out the dissemination of learning multimedia to biology teachers and students of class XI by providing learning multimedia files.

\section{2) The Feasibility of Learning Multimedia}

The results of the validation of the experts showed that the multimedia learning of cell material based on the average obtained was 4.33 which had very valid criteria or was suitable for use in terms of material, media and design. Multimedia learning developed easily operated by the teacher and students who use it. In addition, the developed learning multimedia contains animations, material, videos and practice questions. Practice questions are made to determine student understanding after learning to use multimedia learning. This exercise problem after students work on the exercises will immediately appear the value obtained.

\section{3) Obtaining An Assessment of Students' Attitudes and Skills}

In the aspect of attitude done two times. Observed attitudes include aspects of discipline, responsibility and independence of students. The average percentage of student attitudes showed very good results with an average of 3.5. The results obtained can be seen the value of student attitudes from the initial meeting to the second meeting has increased In aspects according to the data in Figure 1. In general, aspects of discipline have been good from the beginning, but from the initial meeting to the next meeting students also have a good chance. Students orderly follow instructions, are active in learning and utilize existing media.

In the aspect of student skills performed two times. The skills observed include aspects of students brave or enthusiastic about asking questions and answering questions from teachers and other students. The average student skills showed very good results with an average of 3.6. The results obtained can be seen the value of student skills from the initial meeting to the second meeting has increased in every aspect in accordance with the data in Fig. 2. In general, students are enthusiastic in asking and answering questions.

\section{CONCLUSIONS}

Based on the results of research that has been done can be concluded as follows: (1) Multimedia learning using the 4D model through the stages of define, design, develop and disseminate to produce a media that uses lectora software and is packaged in a flash disk. (2) Multimedia learning is declared feasible to use after fulfilling the validity aspects based on average material validation of 4.50 (very valid), average media validation of 4.06 (valid) and average learning design validation of 4.44 (very valid). (3) The assessment of students' attitudes and skills in the learning process using multimedia learning obtained an average of 3.5 and 3.6 indicating a very good category. (4) This development produces media in the form of multimedia learning that has been validated by validation experts and can help teachers in the learning process in order to create interesting lessons for students.

\section{REFERENCES}

Cahyaningtyas, Renyta. (2017). Pengembangan Media pembelajaran Interaktif Pada Materi Sistem Ekskresi Manusia Untuk SMP Kelas VIII. EJournal Pensa, 5(3).

Daryanto. (2016). Media Pembelajaran. Yogyakarta: Gava Media.

Diputra, K.S. (2016). Pengembangan Multimedia Pembelajaran Tematik Integratif Untuk Siswa Kelas IV Sekolah Dasar. Jurnal Pendidikan Indonesia, $5(2)$.

Hamalik, Oemar. (2005). Perencanaan Pengajaran Berdasarkan Pembelajaran Sistem. Jakarta: PT Bumi Aksara.

Krisnawati, Titik (2014). Pengembangan Multimedia Pembelajaran Untuk Mata Pelajaran Biologi di SMA. Jurnal Ilmiah Guru “COPE”, 18(2).

Munir. (2015). Multimedia Konsep \& Aplikasi Dalam Pendidikan. Bandung: Alfabeta.

Pribadi, Benny A. (2018). 21 Konsep Esensial dalam Teknologi Pendidikan. Jakarta: PT Dian Rakyat.

Rusman. (2013). Belajar dan Pembelajaran Berbasis Komputer. Bandung: Alfabeta.

Sofyan et al. (2011). Pengembangan Multimedia Pembelajaran untuk Meningkatkan Hasil Belajar Kognitif Materi Sistem Respirasi. Universitas Negeri Malang.

Sugiyono. (2014). Metode Penelitian Kuantitatif Kualitatif dan $R \& D$. Bandung: Alfabeta.

Sukmadinata, Nana, S. (2017). Metode Penelitian Pendidikan. Bandung: PT Remaja Rosdakarya.

Suryani et al. (2018). Media Pembelajaran Inovatif dan Pengembangannya. Bandung: Remaja Rosdakarya.

Yanti and Eka. (2017). Pengembangan Media Pembelajaran Biologi Berbasis Adobe Flash Pada Materi Pembelahan Sel Kelas XII SMA Negeri 1 Sungai Raya. Jurnal Bioeducation, 2(1). 